\title{
Higher total white blood cell and neutrophil counts are associated with an increased risk of fatal stroke occurrence: the Guangzhou biobank cohort study
}

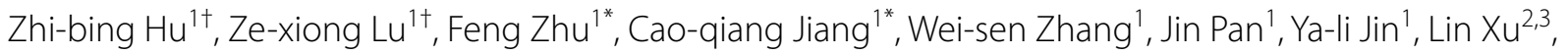
G. Neil Thomas ${ }^{4}$, Karkeung Cheng ${ }^{4}$ and Taihing Lam ${ }^{1,2,3}$

\begin{abstract}
Background: Chronic inflammatory diseases are linked to an increased risk of stroke events. The white blood cell (WBC) count is a common marker of the inflammatory response. However, it is unclear whether the WBC count, its subpopulations and their dynamic changes are related to the risk of fatal stroke in relatively healthy elderly population.
\end{abstract}

Methods: In total, 27,811 participants without a stroke history at baseline were included and followed up for a mean of 11.5 (standard deviation =2.3) years. After review of available records, 503 stroke deaths (ischaemic 227, haemorrhagic 172 and unclassified 104) were recorded. Cox proportional hazards regression was used to assess the associations between the WBC count, its subpopulations and their dynamic changes (two-phase examination from baseline to the 1st follow-up) and the risk of fatal all stroke, fatal ischaemic stroke and fatal haemorrhagic stroke.

Results: (i) Regarding the WBC count in relation to the risk of fatal stroke, restricted cubic splines showed an atypically U-curved association between the WBC count and the risk of fatal all stroke occurrence. Compared with those in the lowest WBC count quartile $\left(<5.3^{*} 10^{\wedge} 9 / \mathrm{L}\right)$, the participants with the highest WBC count $\left(>7.2^{*} 10 \wedge 9 / \mathrm{L}\right)$ had a 53 and $67 \%$ increased risk for fatal all stroke (adjusted hazard ratio [aHR] $=1.53,95 \%$ confidence interval (CI) $1.16-2.02$, $P=0.003)$ and fatal haemorrhagic stroke (aHR $=1.67,95 \% \mathrm{Cl} 1.10-2.67, P=0.03)$, respectively; compared with those in the lowest quartile $\left(<3.0^{*} 10^{\wedge} 9 / \mathrm{L}\right)$, the participants with the highest NEUT count $\left(>4.5^{*} 10^{\wedge} 9 / \mathrm{L}\right)$ had a 45 and $65 \%$ increased risk for fatal all stroke $(\mathrm{aHR}=1.45,95 \% \mathrm{Cl} 1.10-1.89, P=0.008)$ and fatal ischaemic stroke $(\mathrm{aHR}=1.65,95 \% \mathrm{Cl}$ 1.10-2.47 $P=0.02$ ), respectively. With the additional adjustment for $C$-reactive protein, the same results as those for all stroke and ischaemic stroke, but not haemorrhagic stroke, were obtained for the WBC count $\left(4 \sim 10^{*} 10^{\wedge} 9 / \mathrm{L}\right)$ and the NEUT count (the NEUT counts in the top $1 \%$ and bottom 1\% at baseline were excluded). (ii) Regarding dynamic changes in the WBC count in relation to the risk of fatal stroke, compared with the stable group (-25\% 25\%, dynamic changes from two phases of examination (baseline, from September 1st, 2003 to February 28th, 2008; 1st follow-up, from March 31 st 2008 to December 31st 2012)), the groups with a 25\% increase in the WBC count and

\footnotetext{
*Correspondence: chifengzhu@hotmail.com; jcqiang@163.com

${ }^{\dagger}$ Zhi-bing Hu and Ze-xiong Lu are joint first author.

${ }^{1}$ Guangzhou Twelfth People's Hospital, Guangzhou, China

Full list of author information is available at the end of the article
}

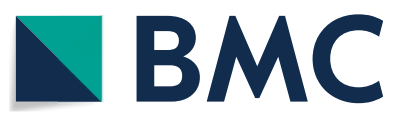

(c) The Author(s) 2021. Open Access This article is licensed under a Creative Commons Attribution 4.0 International License, which permits use, sharing, adaptation, distribution and reproduction in any medium or format, as long as you give appropriate credit to the original author(s) and the source, provide a link to the Creative Commons licence, and indicate if changes were made. The images or other third party material in this article are included in the article's Creative Commons licence, unless indicated otherwise in a credit line to the material. If material is not included in the article's Creative Commons licence and your intended use is not permitted by statutory regulation or exceeds the permitted use, you will need to obtain permission directly from the copyright holder. To view a copy of this licence, visit http://creativecommons.org/licenses/by/4.0/. The Creative Commons Public Domain Dedication waiver (http://creativecommons.org/publicdomain/zero/1.0/) applies to the data made available in this article, unless otherwise stated in a credit line to the data. 
NEUT count respectively had a $60 \%(\mathrm{aHR}=1.60,95 \% \mathrm{Cl} 1.07-2.40, P=0.02)$ and $45 \%(\mathrm{aHR}=1.45,95 \% \mathrm{Cl} .02-2.05$, $P=0.04)$ increased risk of fatal all stroke occurrence.

Conclusions: The WBC count, especially the NEUT count, was associated with an increased risk of fatal all stroke occurrence. Longitudinal changes in the WBC count and NEUT count increase in excess of $25 \%$ were also associated with an increased risk of fatal all stroke occurrence in the elderly population.

Keywords: Stroke, WBC, Neutrophil, Ischaemic, Haemorrhagic, Cohort

\section{Background}

Stroke is classified mainly as ischaemic and haemorrhagic stroke [1]. With the high prevalence of comorbidities in developed Western countries, pre-existing chronic low-grade systemic inflammation has become a recognized characteristic of stroke pathophysiology [2]. Evidence now suggests that a chronic inflammatory response is associated with an increased risk of ischaemic $[3,4]$ and haemorrhagic [5] stroke. The total white blood cell (WBC) count, a plausible marker in the pathogenesis of chronic inflammation [6], is generally conducive to stroke incidence.

A higher WBC count on admission has been linked to poor outcomes, an increased risk of stroke mortality [7, 8], ischaemic stroke [9] and haemorrhagic stroke [10] in case-control studies. However, these WBC counts may be due to the stress reaction in acute patients with stroke [2], and it is not clear whether these higher WBC counts are linked directly to stroke death. On the other hand, a relatively high WBC count has been linked to stroke incidence, unfavourable functional outcomes and increased risks of fatal stroke [11-15] and ischaemic stroke [13, 15-20] in prospective cohort studies, although this is still controversial in the context of stroke [21], ischaemic stroke [22, 23] and haemorrhagic stroke [15, 19]. Similar associations have been shown between neutrophils, the largest WBC subpopulation, and stroke $[8,15]$, ischaemic stroke $[15,19,20,24-26]$ and haemorrhagic stroke [27]. However, different types of inflammation can result in increases in not only WBCs but also other indicators such as C-reactive protein (CRP). CRP, a controversial independent risk factor for stroke and an underlying acute inflammatory risk factor [2], has been reported to be a predictor of stroke $[13,28]$ and ischaemic stroke [23, $26,29,30]$. Nevertheless, to date, no changes in the WBC count or its subpopulations have been reported to be linked to the risk of fatal stroke.

In previous work, we reported that a higher WBC count was associated with all-cause, CHD (coronary heart disease) and respiratory mortality [14], cardiovascular disease [31] and metabolic syndrome risk [32] in the Guangzhou Biobank Cohort Study (GBCS). Here, we aimed to systematically assess the relationships between the WBC count, its subpopulations and their changes and the risks of fatal all stroke, fatal ischaemic stroke and fatal haemorrhagic stroke among a relatively healthy elderly population in southern China.

\section{Methods}

Participants

All participants were recruited from a population of permanent residents aged 50 years or above in Guangzhou in southern China. Details of the GBCS, targetting an elderly population, have been reported previously [33]. The baseline (from September 1st, 2003, to February 28th, 2008) and follow-up information included a faceto-face computer-assisted interview by trained nurses on lifestyle [34], the family and personal medical history and assessments of anthropometrics, blood pressure and laboratory tests. Each participant had made an appointment in advance to ensure good health, was able to come the designated place by himself/herself and was able to sit and rest for at least half an hour before sampling and examination.

\section{Exposure indicators}

The WBC count and subpopulation counts were performed with a blood cell counter (KX-21, Sysmex, Japan) in Guangzhou Twelfth People's Hospital. The WBC, neutrophil (NEUT) and lymphocyte (LYM) counts were determined separately, while monocyte, eosinophil and basophil counts were determined automatically as a mixture (named MXDs). Fasting glucose, cholesterol, triglycerides, liver and kidney function and CRP were measured with an analyser (Cobas c-311, Roche, Switzerland). The hospital laboratory runs internal and external quality control procedures according to the China Association of Laboratory Quality Control.

\section{Study outcomes}

Information on underlying causes of death up to December 31st, 2017, was obtained mostly via record linkage with the Guangzhou Centers for Disease Control and Prevention (GZCDC). Because there was no other information for stroke severity, infarct volume, site of lesion and infectious complications, fatal stroke occurrence was chosen as the primary outcome of this study. Death causes were coded according to the 10th revision of the 
International Classification of Diseases (ICD) as follows: I60 I69 for stroke; I60.0 I62.9 and I69.0 I69.2 for haemorrhagic stroke; I63.0 I63.9 and I69.3 for ischaemic stroke; and the other codes for unclassified stroke. When the death certificates were not issued by medical institutions, the causes were verified by GZCDC as part of their quality assurance programmed by cross-checking past medical history and conducting verbal autopsy by 5 senior clinicians from Guangzhou Twelfth People's Hospital, the Universities of Hong Kong, China and Birmingham, UK.

\section{Potential confounders}

To examine the extent to which baseline factors explained the associations of stroke, ischaemic stroke and haemorrhagic stroke, we included the factors in different models. Model 1 was a crude hazard ratio model without adjustment for any confounders. Model 2 contained multivariate adjustments including sex, age, education (primary and below, middle school, and college or above), occupation (manual, nonmanual, and others), smoking (never, former and current), alcohol consumption (never, former and current), International Physical Activity Questionnaire-assessed physical activity (inactive, moderate and active) [34], body mass index (BMI, defined as weight in $\mathrm{kg} \div$ eight in $\mathrm{m}^{2}$ ) [35], self-rated health (good, very good), hypertension, diabetes, dyslipidaemia, cancer, genitourinary disease (nephropathy, prostatic disease, and gynaecologic diseases), chest disease (chronic obstructive pulmonary disease, chronic bronchitis, emphysema, asthma, tuberculosis, and pneumonia) and the platelet count. Model 3 included CRP as a competing confounder in addition to the confounders in model 2.

\section{Statistical analysis}

The WBC count was first analysed as a continuous parameter using a restricted cubic spline curve model with 3 knots at the 10th, 50th, and 90th percentiles of WBC counts. The WBC counts were also classified by quartiles. Categories of WBC, NEUT and LYM counts were defined as the following quartiles: 1st quartile $\left(<5.3^{*} 10^{\wedge} 9 / \mathrm{L}\right)$, 2nd quartile $\left(5.3-6.1^{*} 10^{\wedge} 9 / \mathrm{L}\right)$, 3rd quartile $\left(6.2-7.2^{*} 10^{\wedge} 9 / \mathrm{L}\right)$ and 4 th quartile $\left(>7.2^{*} 10^{\wedge} 9 / \mathrm{L}\right)$ for the WBC count; 1st quartile $\left(<3.0^{*} 10^{\wedge} 9 / \mathrm{L}\right)$, 2nd quartile $\left(3.0-3.6^{*} 10^{\wedge} 9 / \mathrm{L}\right)$, 3rd quartile $\left(3.7-4.4^{*} 10^{\wedge} 9 / \mathrm{L}\right)$ and 4 th quartile $\left(>4.5^{*} 10^{\wedge} 9 / \mathrm{L}\right)$ for the NEUT count; and 1st quartile $\left(<1.8^{*} 10^{\wedge} 9 / \mathrm{L}\right)$, 2nd quartile $\left(1.8-2.1^{*} 10^{\wedge} 9 / \mathrm{L}\right)$, 3rd quartile $\left(2.2-2.5^{*} 10^{\wedge} 9 / \mathrm{L}\right)$ and 4 th quartile $\left(>2.5^{*} 10^{\wedge} 9 / \mathrm{L}\right)$ for the LYM count. For analysis on longitudinal WBC count changes, we chosed one follow up closest to baseline, thus only those who participated in the 1st follow-up (from March 2008 to December 2012) were included, and the follow-up period started from baseline (September
2003 to February 2008); an exposure period was therefore followed by the beginning of baseline. Two groups $( \pm 10$ and $\pm 25 \%)$ were formed, with each group being drawn from those with two exposures and those who survived. Continuous variables are presented as the mean \pm standard deviation, and categorical variables as presented as the frequency and percentage. The chi-squared and Fisher's exact tests were used for categorical variables, and analysis of variance (ANOVA) and Kruskal-Wallis tests were used for continuous variables. Based on the results of the crude hazard ratio model analysis, a sensitivity analysis was conducted in which model 2 and model 3 were repeated for the participants with a normal range of WBC count $\left(4 \sim 10^{*} 10^{\wedge} 9 / \mathrm{L}\right)$ and with a NEUT count exclusion (The NEUT counts within the top $1 \%$ and bottom $1 \%$ at baseline were excluded. This exclusion was because of no normal range of NEUT count, and was to avoid cases with a significantly low or high NEUT count, though the number of such cases was small, and to avoid more loss of raw data). All analyses were performed using STATA (Version 14.0; StataCorp LP, College Station, TX, USA). All $p$ values were 2 sided, and statistical significance was defined as $p<0.05 ; p$ values for trends in the models were calculated as ordinal scores from the 2nd, 3rd and 4th quartiles when taking the 1st quartile as the reference.

\section{Results}

\section{Baseline characteristics}

In total, 30,430 participants were screened. Among participant data exclusions, there were 286 because of a previous history of stroke, 315 because of an unclear stroke history, 372 because of loss to follow-up with unknown vital status, and 1646 because of incomplete information on the WBC, NEUT, LYM and platelet counts, hypertension, diabetes, dyslipidaemia, smoking, alcohol consumption, physical activity, BMI, self-rated health, cancer, genitourinary disease or chest disease. A total of 27,811 participants who were free of stroke at baseline were included in this study. After a mean follow-up time of 11.5 (standard deviation $=2.3$ ) years with 320,859 person-years, 503 stroke deaths (227 ischaemic, 172 haemorrhagic and 104 unclassified) were recorded (Fig. 1).

The baseline characteristics of the participants are presented in Table 1. Compared to the population in the 1st WBC quartile, the population in the 2nd to the 4th quartiles had a higher proportion of men; were older; had a higher proportion of manual occupations; had a higher proportion of former or current smokers and drinkers; had higher proportions of individuals with BMIs $\geq 24 \mathrm{~kg} /$ $\mathrm{m} 2$, hypertension, diabetes and dyslipidaemia; had higher NEUT, LYM, and platelet counts and CRP levels; had a lower educational level; and had less physical activity, 
30,430 participants recruited for baseline of the Guangzhou Biobank Cohort Study
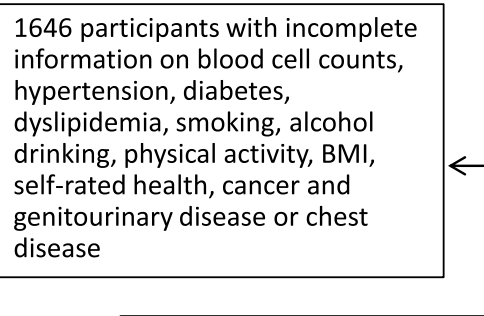
27,811 participants being free of stroke at baseline were recorded in this study (from September 2003 to February 2008)

16296 participants conducted the $1^{\text {st }}$ follow-up (from March 2008 to December 2012)
Underlying deaths up to December 2017 via record linkage with the Guangzhou Centre for Disease Control and Prevention

503 stroke deaths were recorded

(227 ischaemic stroke, 172 haemorrhagic stroke and 104 unclassified stroke)

Fig. 1 Flow diagram of participants selected for the analysis of this study

poorer self-rated health, and more cancer and genitourinary disease (all $P<0.001)$.

\section{The WBC count in relation to the risk of fatal stroke occurrence}

Our restricted cubic splines showed an atypically U-shaped association between the WBC count and the risk of fatal all stroke occurrence, and a WBC count of $6.3 * 10^{\wedge} 9 / \mathrm{L}$ was linked to the lowest risk of fatal all stroke occurrence after adjustments were made for potential confounders in model 2 (Fig. 2). Different risks of fatal all stroke occurrence were observed in the highest WBC quartile $(\mathrm{aHR}=1.60,95 \% \mathrm{CI} 1.24-2.07, P<0.001)$ and the lowest $\mathrm{WBC}$ quartile $(\mathrm{aHR}=1.05,95 \% \mathrm{CI} 0.78-1.40$, $P=0.76)$ when the $2^{\text {ed }} \mathrm{WBC}$ quartile was taken as reference (Supplementary Table 1).

The left side of Table 2 shows the higher WBC counts in relation to the increased risk of fatal stroke. After adjustments for a series of factors, participants in the 4th WBC quartile $\left(>7.2^{*} 10^{\wedge} 9 / \mathrm{L}\right)$ had increased risks of fatal all stroke $(\mathrm{aHR}=1.53,95 \% \mathrm{CI} 1.16-2.02, P=0.003)$ and fatal haemorrhagic stroke (aHR $=1.67,95 \%$ CI $1.05-2.67$, $P=0.03)$ but not fatal ischaemic stroke $(\mathrm{aHR}=1.45$, 95\% CI 0.96-2.18, $P=0.08$ ) compared to participants in the 1 st WBC quartile $\left(<5.3^{*} 10^{\wedge} 9 / \mathrm{L}\right)$. The participants in the 2nd, 3rd and 4th WBC quartiles had increasing risk trends for fatal all stroke $(P<0.001)$, fatal ischaemic stroke $(P=0.01)$ and fatal haemorrhagic stroke $(P=0.02)$. The middle of Table 2 shows the NEUT count in four quartiles. Significant associations with increased risks were fatal all stroke $(\mathrm{aHR}=1.45,95 \% \mathrm{CI} 1.10-1.89$, $P=0.008)$ and fatal ischaemic stroke $(\mathrm{aHR}=1.65,95 \% \mathrm{CI}$ 1.10-2.47, $P=0.02$ ). Unlike the WBC count, the NEUT count showed neither a higher risk (aHR $=1.14,95 \% \mathrm{CI}$ $0.74-1.75, P=0.56)$ nor an increasing trend $(P=0.26)$ for fatal haemorrhagic stroke (Supplementary Fig. 1).

With the additional adjustment for CRP, the participants in the 4th WBC quartile had a significant association only for fatal all stroke $(\mathrm{aHR}=1.57,95 \% \mathrm{CI}$ 1.02-2.42, $P=0.04$ ), but an increasing risk trend was evident for both fatal all stroke $(P=0.012)$ and fatal ischaemic stroke $(P=0.02)$ among 10,041 participants with normal WBC counts $\left(4 \sim 10^{*} 10^{\wedge} 9 / \mathrm{L}\right)$ (Left side of Table 3). The participants in the highest NEUT quartile had an increased risk for both fatal all stroke $(\mathrm{aHR}=1.55$, 95\% CI 1.00-2.41, $P=0.05)$ and fatal ischaemic stroke $(\mathrm{aHR}=2.47,95 \% \mathrm{CI} 1.24-4.93, P=0.01)$, and an increasing risk trend was evident for both fatal all stroke $(P=0.009)$ and fatal ischaemic stroke $(P=0.004)$ among 9946 participants, with the NEUT count in the top $1 \%$ and bottom $1 \%$ being excluded; however, the higher NEUT count showed neither a significant association 
Table 1 Baseline characteristics by WBC quartiles of participants in the GBCS, 2003-2017 $(n=27,811)$

\begin{tabular}{|c|c|c|c|c|c|}
\hline \multirow[t]{2}{*}{ Characteristics } & \multicolumn{4}{|c|}{ Quartiles of WBC $(* 10 \wedge 9 / L)$} & \multirow[t]{2}{*}{$P$ value trend } \\
\hline & 1 st $(<5.3)$ & 2nd (5.3-6.1) & $3 r d(6.2-7.2)$ & 4 th $(>7.2)$ & \\
\hline Number, $\mathrm{n}$ & 6946 & 6912 & 7093 & 6860 & \\
\hline Sex, male(\%) & $1468(21.1)$ & $1767(25.6)$ & $2004(28.3)$ & $2392(34.9)$ & $<0.001$ \\
\hline Age (years) & $61.1 \pm 7.1$ & $61.8 \pm 7.2$ & $62.3 \pm 7.0$ & $62.9 \pm 7.0$ & $<0.001$ \\
\hline Education (\%) & & & & & $<0.001$ \\
\hline Primary or below & $2536(36.5)$ & $2861(41.4)$ & $3177(44.8)$ & $3406(49.7)$ & \\
\hline Middle school & $3685(53.1)$ & $3405(49.3)$ & $3352(47.3)$ & $2932(42.7)$ & \\
\hline College or above & $725(10.4)$ & $646(9.3)$ & $564(8.0)$ & $522(7.6)$ & \\
\hline Occupation & & & & & $<0.001$ \\
\hline Manual & $3277(47.2)$ & $3346(48.4)$ & $3551(50.1)$ & $3565(52.0)$ & \\
\hline Non-manual & $2267(32.6)$ & $2262(32.7)$ & $2294(32.3)$ & $2130(31.0)$ & \\
\hline Others & $1402(22.2)$ & $1304(18.9)$ & $1248(17.6)$ & $1165(17.0)$ & \\
\hline Smoking, n (\%) & & & & & $<0.001$ \\
\hline Never & $6086(87.6)$ & $5822(84.2)$ & $5708(80.5)$ & $4909(71.6)$ & \\
\hline Former & $530(7.6)$ & $596(8.6)$ & $682(9.6)$ & $714(10.4)$ & \\
\hline Current & $330(4.8)$ & $494(7.2)$ & $703(9.9)$ & $1237(18.0)$ & \\
\hline Alcohol drinking, n (\%) & & & & & $<0.001$ \\
\hline Never & $5016(72.2)$ & $4835(70.0)$ & $4965(70.0)$ & $4725(68.9)$ & \\
\hline Former & $119(1.7)$ & $150(2.2)$ & $169(2.4)$ & $203(3.0)$ & \\
\hline Current & $1811(26.1)$ & $1927(27.8)$ & $1959(27.6)$ & $1932(28.1)$ & \\
\hline Physical activity, IPAQ, n (\%) & & & & & $<0.001$ \\
\hline Inactive & $649(9.3)$ & $505(7.3)$ & $560(7.9)$ & $541(7.9)$ & \\
\hline Moderate active & $2844(41.0)$ & $2771(40.1)$ & $2855(40.2)$ & $2876(41.9)$ & \\
\hline Active & $3453(49.7)$ & $3636(52.6)$ & $3678(51.9)$ & $3443(50.2)$ & \\
\hline Body mass index, $\mathrm{kg} / \mathrm{m}^{2}$ & & & & & $<0.001$ \\
\hline$<18.5$ & $562(8.1)$ & $295(4.3)$ & $199(2.8)$ & $190(2.8)$ & \\
\hline $18.5-23.9$ & $4119(59.3)$ & $3608(52.2)$ & $3339(47.1)$ & $2882(42.0)$ & \\
\hline $24-27.9$ & $1909(27.5)$ & $2429(35.1)$ & $2734(38.5)$ & $2785(40.6)$ & \\
\hline$\geq 28$ & $356(5.1)$ & $580(8.4)$ & $821(11.6)$ & $1003(14.6)$ & \\
\hline $\begin{array}{l}\text { Self-rated health, n (\%) } \\
\text { (good/very good) }\end{array}$ & $5724(82.4)$ & $5793(83.8)$ & $5899(83.2)$ & $5561(81.1)$ & $<0.001$ \\
\hline Hypertension, n (\%) & $1462(21.0)$ & $1748(25.3)$ & $2189(30.9)$ & $2417(35.2)$ & $<0.001$ \\
\hline Diabetes, n (\%) & $522(7.5)$ & $751(10.9)$ & $997(14.1)$ & $1359(19.8)$ & $<0.001$ \\
\hline Dyslipidemia, n (\%) & $5517(79.4)$ & $5694(82.4)$ & $5985(84.4)$ & $5828(85.0)$ & $<0.001$ \\
\hline Cancer, n (\%) & $180(2.6)$ & $137(2.0)$ & $122(1.7)$ & $100(1.5)$ & $<0.001$ \\
\hline GU disease, n (\%) & $2035(29.3)$ & $1873(27.1)$ & $1853(26.1)$ & $1644(24.0)$ & $<0.001$ \\
\hline Chest disease, n (\%) & $1060(15.3)$ & $1076(15.6)$ & $1039(14.6)$ & $1038(15.1)$ & 0.50 \\
\hline NEUT, ${ }^{*} 10 \wedge 9 / \mathrm{L}$ & $2.6 \pm 0.76$ & $3.3 \pm 0.47$ & $4.0 \pm 0.95$ & $5.4 \pm 1.24$ & $<0.001$ \\
\hline LYM, * $10 \wedge 9 / L$ & $1.7 \pm 0.36$ & $2.0 \pm 0.41$ & $2.2 \pm 0.48$ & $2.6 \pm 0.67$ & $<0.001$ \\
\hline Platelet, ${ }^{*} 10 \wedge 9 / \mathrm{L}$ & $203.6 \pm 51.3$ & $221.6 \pm 57.7$ & $233.9 \pm 55.7$ & $250.4 \pm 65.8$ & $<0.001$ \\
\hline CRP, mg/L & $2.8 \pm 2.4$ & $3.1 \pm 2.5$ & $3.6 \pm 2.8$ & $4.2 \pm 3.2$ & $<0.001$ \\
\hline No. of all stroke deaths & $89(0.013)$ & $98(0.014)$ & $136(0.019)$ & $180(0.026)$ & $<0.001$ \\
\hline No. of ischaemic stroke & $42(0.0060)$ & $39(0.0056)$ & $66(0.0093)$ & $80(0.012)$ & $<0.001$ \\
\hline No. of haemorrhagic stroke & $32(0.0046)$ & $37(0.0054)$ & $42(0.0059)$ & $63(0.0092)$ & $<0.001$ \\
\hline
\end{tabular}

Hypertension: systolic blood pressure, $\geq 140 \mathrm{mmHg}$, diastolic blood pressure, $\leq 90 \mathrm{mmHg}$, medication or diagnosis; diabetes: fasting blood glucose $\geq 7$, medication or diagnosis; dyslipidaemia: total cholesterol $\geq 5.2 \mathrm{mmol} / \mathrm{L}$, triglyceride $\geq 1.7 \mathrm{mmol} / \mathrm{L}$, low density lipoprotein $\geq 3.4 \mathrm{mmol} / \mathrm{L}$, high density lipoprotein $<1.0 \mathrm{mmol} / \mathrm{L}$, medication or diagnosis; WBC White blood cell, CRP C-reactive protein, GU Genitourinary disease (including nephropathy, prostatic disease, and gynaecologic diseases); chest disease (including chronic obstructive pulmonary disease, chronic bronchitis, emphysema, asthma, tuberculosis, and pneumonia) 


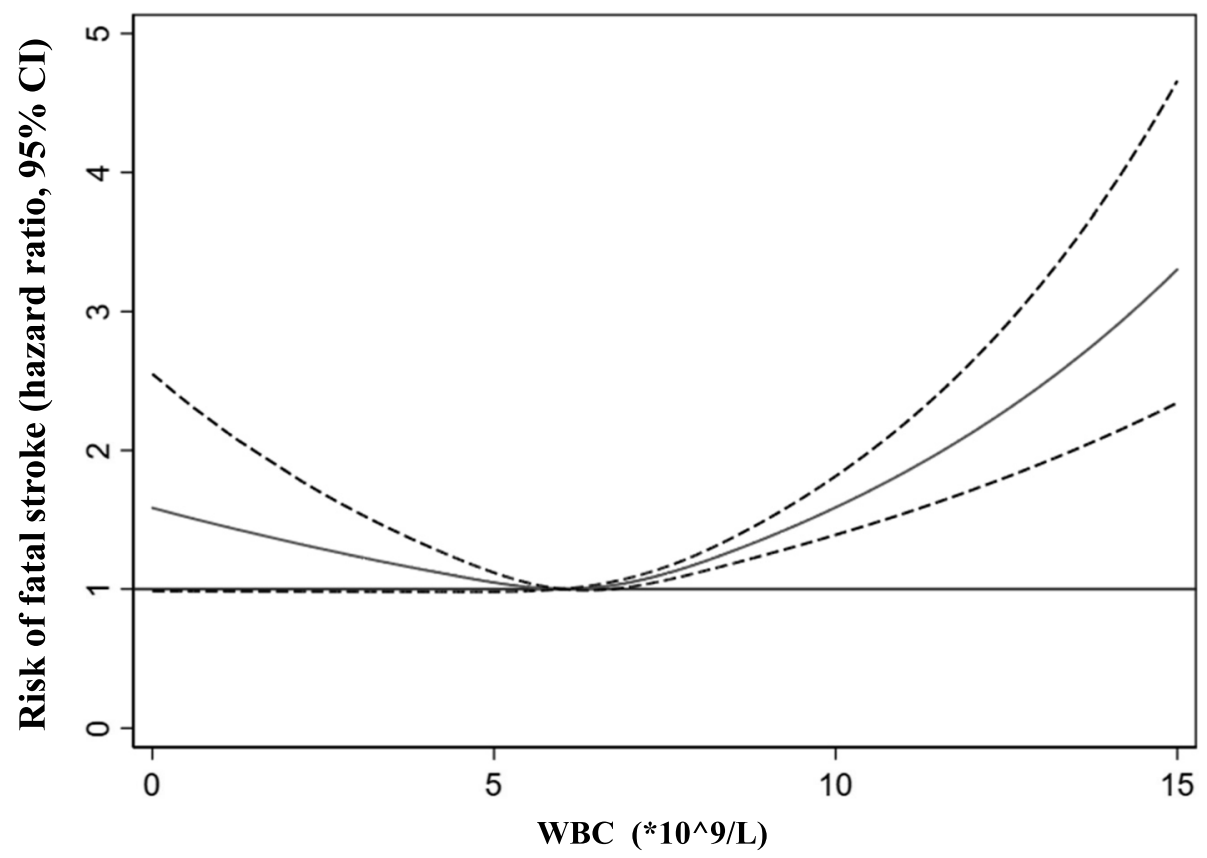

Fig. 2 Association between the risk of fatal all stroke and WBC count on a continuous scale with restricted cubic spline curves based on Cox proportional hazards models in the GBCS followed for a mean 11.5 years. The solid blue line is the multivariable adjusted hazard ratio, with dashed lines showing $95 \%$ confidence intervals with three knots. A multivariate model adjusted for sex, age, education, occupation, diabetes, hypertension, dyslipidaemia, smoking, alcohol consumption, physical activity, body mass index, self-rated health, cancer, genitourinary diseases, chest disease and platelet count was used.

$(P=0.18)$ nor an increasing risk trend $(P=0.40)$ for fatal haemorrhagic stroke (Right side of Table 3).

Additionally, the LYM count showed only a decreased risk trend for fatal ischaemic stroke $(P$ for crude HR $=0.03$ ). No significant association between fatal all stroke and the CRP level was observed (Table 4).

\section{WBC changes in relation to the risk of fatal stroke occurrence}

The basic characteristics of the participants at the 1st follow-up are shown in Supplementary Table 2. Compared with that with a stable WBC count (from -25 to $25 \%$ ), the population with a WCB count gain (at $>25 \%$ ) had higher proportions of manual occupations, former smokers and current drinkers; had higher proportions of moderate activity, BMIs $\geq 28 \mathrm{~kg} / \mathrm{m}^{2}$, hypertension, cancer and chest diseases; lower proportions of other occupations, physical activity, and BMIs from 24 to $27.9 \mathrm{~kg} / \mathrm{m}^{2}$; and lower WBC and NEUT counts (all $P<0.05$ ).

Table 5 shows the association between the risk of fatal stroke and a change in the WBC count during the period from baseline (from September 2003 to February 2008) to the 1st follow-up (from March 2008 to December 2012). Compared to the stable participants, participants with WBC or NEUT count changes within $10 \%$ had no significant risk of fatal all stroke. Once the change reached 25\% increased, a significant risk of fatal all stroke was present for both the WBC count $(\mathrm{aHR}=1.60,95 \% \mathrm{CI}$ $1.07-2.40, P=0.02)$ and NEUT count $(\mathrm{aHR}=1.45,95 \%$ CI $1.02-2.05, P=0.04)$.

\section{Discussion}

In this study, we found that both the WBC and NEUT were associated with the risk of fatal all stroke and that a higher NEUT count was associated with an increased risk of fatal ischaemic stroke. These associations were independent of age, sex, education, occupation, hypertension, diabetes, dyslipidaemia, smoking, alcohol consumption, physical activity, BMI, self-rated health, cancer, genitourinary disease, chest disease, platelet count and CRP.

An increasing number of studies on the relationship between the WBC count and stroke have focused mainly on the population at admission after stroke onset. Most of them support the notion that a higher WBC count is related to a poor outcome or mortality $[8-10,15,26$, $27,36,37]$, except for a few studies reporting disharmony with initial stroke severity $[10,15,30,38]$. This indicates that inflammation arises together with stroke or that the stroke itself leads to leucocytosis or other poor outcomes. In a review [2], a series of biomarkers, including cytokines, the WBC count, CRP and interleukin 6 (IL-6), were shown to participate specifically 
Hu et al. BMC Neurology (2021) 21:470

Page 7 of 15

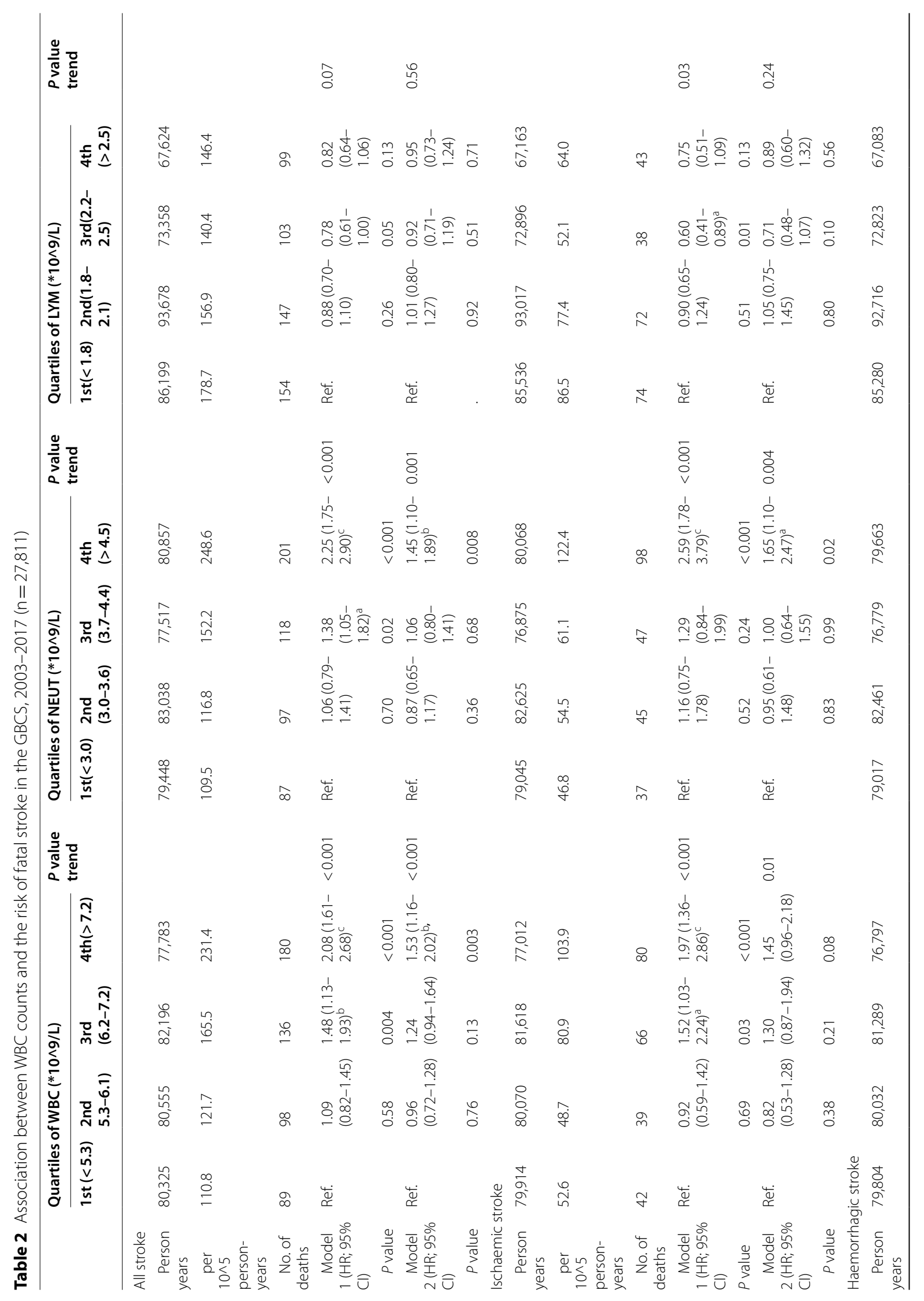


Hu et al. BMC Neurology $\quad$ (2021) 21:470

Page 8 of 15

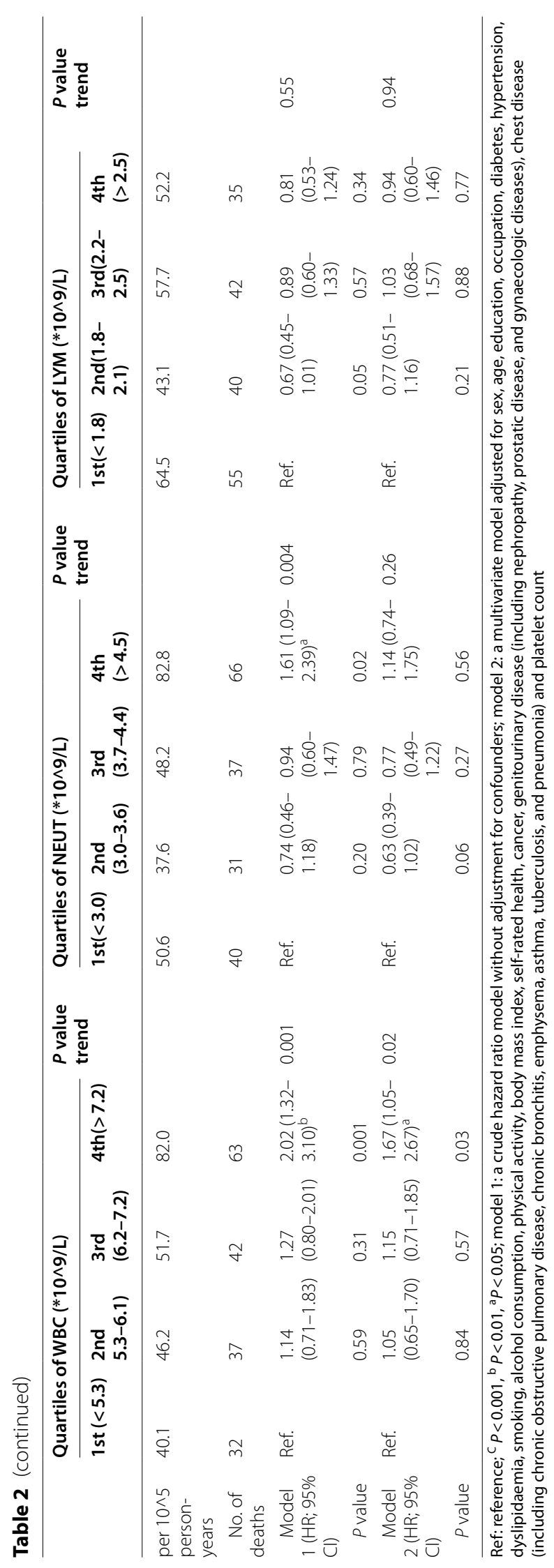




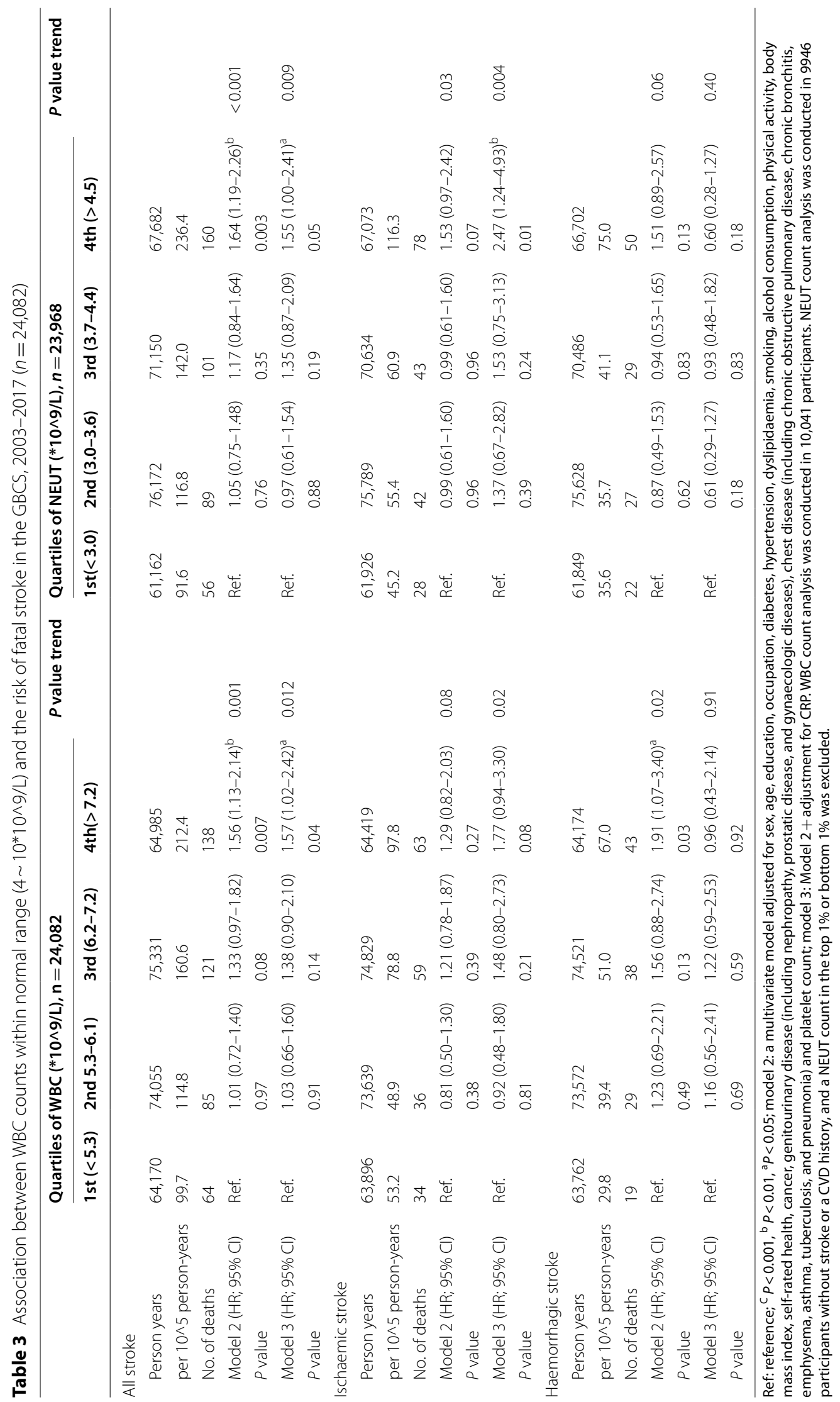




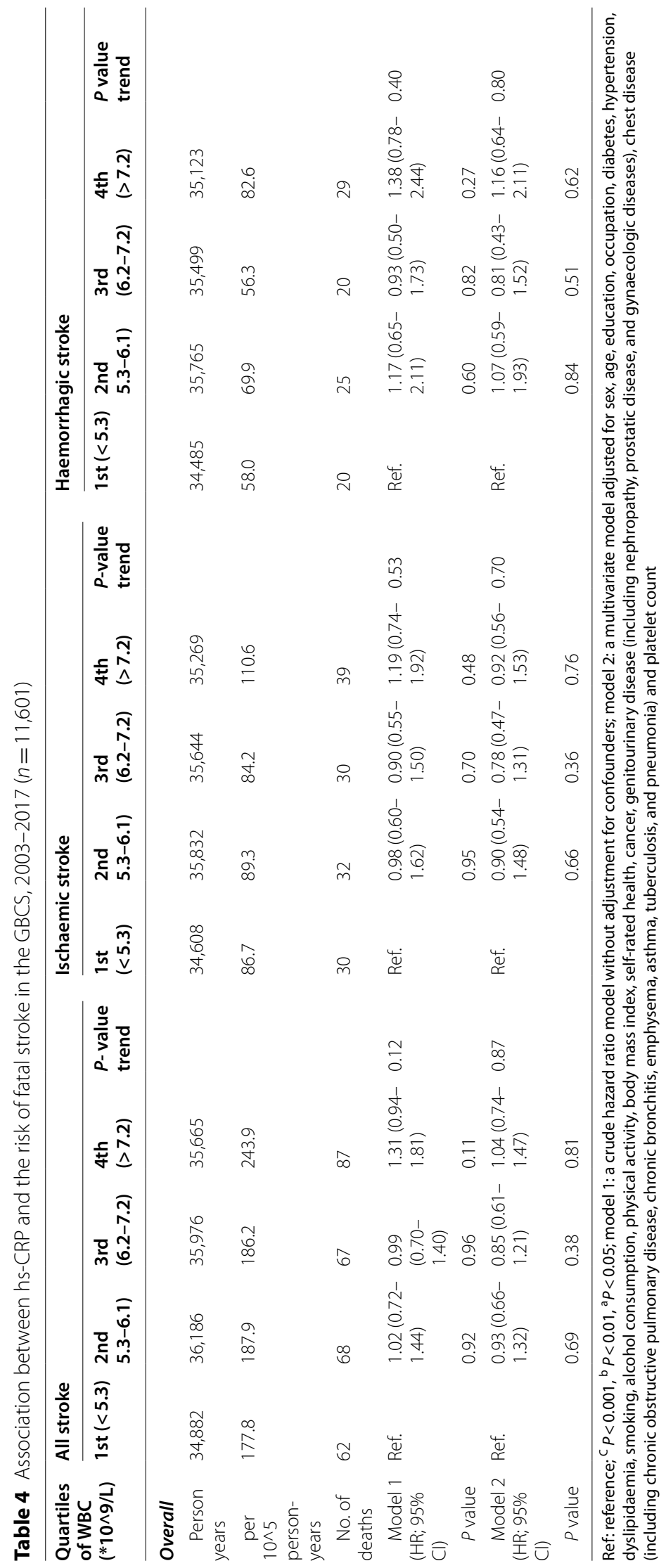


Table 5 Association between WBC count changes and the risk of fatal stroke in the GBCS, 2003-2012 $(n=16,296)$

\begin{tabular}{|c|c|c|c|c|c|c|c|c|c|}
\hline & \multicolumn{3}{|l|}{ All stroke } & \multicolumn{3}{|c|}{ Ischaemic stroke } & \multicolumn{3}{|c|}{ Haemorrhagic stroke } \\
\hline & $\begin{array}{l}\text { Loss } \\
(<-10 \%)\end{array}$ & $\begin{array}{l}\text { Stable } \\
(-10-10 \%)\end{array}$ & $\begin{array}{l}\text { Gain } \\
(>10 \%)\end{array}$ & $\begin{array}{l}\text { Loss } \\
(<-10 \%)\end{array}$ & $\begin{array}{l}\text { Stable } \\
(-10-10 \%)\end{array}$ & $\begin{array}{l}\text { Gain } \\
(>10 \%)\end{array}$ & $\begin{array}{l}\text { Loss } \\
(<-10 \%)\end{array}$ & $\begin{array}{l}\text { Stable } \\
(-10-10 \%)\end{array}$ & $\begin{array}{l}\text { Gain } \\
(>10 \%)\end{array}$ \\
\hline \multicolumn{10}{|l|}{ WBC change } \\
\hline Person years & 33,933 & 57,901 & 36,426 & 33,835 & 57,710 & 36,216 & 33,757 & 57,602 & 36,154 \\
\hline $\begin{array}{c}\text { per } 10^{\wedge} 5 \\
\text { person-years }\end{array}$ & 135.6 & 134.7 & 183.9 & 73.9 & 71.0 & 77.3 & 41.5 & 41.7 & 63.6 \\
\hline $\begin{array}{l}\text { No. of } \\
\text { deaths }\end{array}$ & 46 & 78 & 67 & 25 & 41 & 28 & 14 & 24 & 23 \\
\hline $\begin{array}{l}\text { Model } 1(\mathrm{HR} \text {; } \\
95 \% \mathrm{Cl})\end{array}$ & $\begin{array}{l}1.01 \\
(0.70-1.45)\end{array}$ & Ref. & $\begin{array}{l}1.36 \\
(0.98-1.89)\end{array}$ & $\begin{array}{l}1.05 \\
(0.64-1.73)\end{array}$ & Ref. & $\begin{array}{l}1.08 \\
(0.67-1.74)\end{array}$ & $\begin{array}{l}0.99 \\
(0.51-1.91)\end{array}$ & Ref. & $\begin{array}{l}1.54 \\
(0.87-2.73)\end{array}$ \\
\hline$P$ value & 0.96 & & 0.07 & 0.85 & & 0.76 & 0.97 & & 0.14 \\
\hline $\begin{array}{l}\text { Model } 2(\mathrm{HR} \text {; } \\
95 \% \mathrm{Cl})\end{array}$ & $\begin{array}{l}0.93 \\
(0.64-1.34)\end{array}$ & Ref. & $\begin{array}{l}1.35 \\
(0.97-1.88)\end{array}$ & $\begin{array}{l}0.92 \\
(0.56-1.52)\end{array}$ & Ref. & $\begin{array}{l}1.06 \\
(0.66-1.72)\end{array}$ & $\begin{array}{l}0.94 \\
(0.48-1.82)\end{array}$ & Ref. & $\begin{array}{l}1.48 \\
(0.83-2.63)\end{array}$ \\
\hline$P$ value & 0.70 & & 0.08 & 0.75 & & 0.80 & 0.85 & & 0.18 \\
\hline \multicolumn{10}{|l|}{ NEUT change } \\
\hline Person years & 43,239 & 43,221 & 41,800 & 43,133 & 43,057 & 41,570 & 43,040 & 42,974 & 41,498 \\
\hline $\begin{array}{c}\text { per } 10^{\wedge} 5 \\
\text { person-years }\end{array}$ & 115.6 & 150.4 & 181.8 & 64.9 & 76.6 & 79.4 & 32.5 & 46.5 & 65.1 \\
\hline $\begin{array}{l}\text { No. of } \\
\text { deaths }\end{array}$ & 50 & 65 & 76 & 28 & 33 & 33 & 14 & 20 & 27 \\
\hline $\begin{array}{l}\text { Model } 1 \text { (HR; } \\
95 \% \mathrm{Cl})\end{array}$ & $\begin{array}{l}0.76 \\
(0.53-1.10)\end{array}$ & Ref. & $\begin{array}{l}1.21 \\
(0.87-1.69)\end{array}$ & $\begin{array}{l}0.85 \\
(0.51-1.40)\end{array}$ & Ref. & $\begin{array}{l}1.04 \\
(0.64-1.68)\end{array}$ & $\begin{array}{l}0.69 \\
(0.35-1.36)\end{array}$ & Ref. & $\begin{array}{l}1.41 \\
(0.79-2.52)\end{array}$ \\
\hline$P$ value & 0.15 & & 0.25 & 0.52 & & 0.89 & 0.28 & & 0.24 \\
\hline $\begin{array}{l}\text { Model } 2 \text { (HR; } \\
95 \% \mathrm{Cl})\end{array}$ & $\begin{array}{l}0.72 \\
(0.49-1.04)\end{array}$ & Ref. & $\begin{array}{l}1.18 \\
(0.85-1.65)\end{array}$ & $\begin{array}{l}0.75 \\
(0.45-1.24)\end{array}$ & Ref. & $\begin{array}{l}1.00 \\
(0.61-1.62)\end{array}$ & $\begin{array}{l}0.69 \\
(0.35-1.37)\end{array}$ & Ref. & $\begin{array}{l}1.38 \\
(0.77-2.46)\end{array}$ \\
\hline \multirow[t]{2}{*}{ Pvalue } & 0.08 & & 0.33 & 0.26 & & 0.99 & 0.29 & & 0.28 \\
\hline & Loss $(<-25 \%)$ & $\begin{array}{l}\text { Stable } \\
(-25-25 \%)\end{array}$ & $\begin{array}{l}\text { Gain } \\
(>25 \%)\end{array}$ & $\begin{array}{l}\text { Loss } \\
(<-25 \%)\end{array}$ & $\begin{array}{l}\text { Stable } \\
(-25-25 \%)\end{array}$ & $\begin{array}{l}\text { Gain } \\
(>25 \%)\end{array}$ & $\begin{array}{l}\text { Loss } \\
(<-25 \%)\end{array}$ & $\begin{array}{l}\text { Stable } \\
(-25-25 \%)\end{array}$ & $\begin{array}{l}\text { Gain } \\
(>25 \%)\end{array}$ \\
\hline \multicolumn{10}{|l|}{ WBC change } \\
\hline Person years & 7992 & 107,611 & 12,657 & 7972 & 107,225 & 12,565 & 7936 & 107,055 & 12,522 \\
\hline $\begin{array}{c}\text { per } 10^{\wedge} 5 \\
\text { person-years }\end{array}$ & 162.7 & 139.4 & 221.2 & 112.9 & 67.1 & 103.5 & 46.6 & 46.6 & 63.9 \\
\hline $\begin{array}{l}\text { No. of } \\
\text { deaths }\end{array}$ & 13 & 150 & 28 & 9 & 72 & 13 & 3 & 50 & 8 \\
\hline $\begin{array}{l}\text { Model } 1 \text { (HR; } \\
95 \% \mathrm{Cl})\end{array}$ & $\begin{array}{l}1.18 \\
(0.67-2.08)\end{array}$ & Ref. & $\begin{array}{l}1.58 \\
(1.06-1.37)^{\mathrm{a}}\end{array}$ & $\begin{array}{l}1.72 \\
(0.86-3.43)\end{array}$ & Ref. & $\begin{array}{l}1.53 \\
(0.85-2.76)\end{array}$ & $\begin{array}{l}0.80 \\
(0.25-2.57)\end{array}$ & Ref. & $\begin{array}{l}1.38 \\
(0.65-2.91)\end{array}$ \\
\hline$P$ value & 0.57 & & 0.03 & 0.13 & & 0.16 & 0.71 & & 0.40 \\
\hline $\begin{array}{l}\text { Model } 2(\mathrm{HR} \text {; } \\
95 \% \mathrm{Cl})\end{array}$ & $\begin{array}{l}1.05 \\
(0.59-1.85)\end{array}$ & Ref. & $\begin{array}{l}1.60 \\
(1.07-2.40)^{a}\end{array}$ & $\begin{array}{l}1.48 \\
(0.74-2.98)\end{array}$ & Ref. & $\begin{array}{l}1.58 \\
(0.87-2.87)\end{array}$ & $\begin{array}{l}0.77 \\
(0.24-2.46)\end{array}$ & Ref. & $\begin{array}{l}1.37 \\
(0.65-2.92)\end{array}$ \\
\hline$P$ value & 0.86 & & 0.02 & 0.27 & & 0.13 & 0.65 & & 0.41 \\
\hline \multicolumn{10}{|l|}{ NEUT change } \\
\hline Person years & 17,019 & 89,795 & 21,445 & 16,985 & 89,459 & 21,317 & 16,933 & 89,332 & 21,248 \\
\hline $\begin{array}{c}\text { per } 10 \wedge 5 \\
\text { person-years }\end{array}$ & 129.3 & 140.3 & 200.5 & 94.2 & 63.7 & 98.5 & 29.5 & 48.1 & 61.2 \\
\hline $\begin{array}{l}\text { No. of } \\
\text { deaths }\end{array}$ & 22 & 126 & 43 & 16 & 57 & 21 & 5 & 43 & 13 \\
\hline $\begin{array}{l}\text { Model } 1 \text { (HR; } \\
95 \% \mathrm{Cl})\end{array}$ & $\begin{array}{l}0.92 \\
(0.59-1.45)\end{array}$ & Ref. & $\begin{array}{l}1.43 \\
(1.02-2.03)^{a}\end{array}$ & $\begin{array}{l}1.49 \\
(0.86-2.60)\end{array}$ & Ref. & $\begin{array}{l}1.54 \\
(0.94-2.55)\end{array}$ & $\begin{array}{l}0.61 \\
(0.24-1.53)\end{array}$ & Ref. & $\begin{array}{l}1.29 \\
(0.69-2.39)\end{array}$ \\
\hline$P$ value & 0.72 & & 0.04 & 0.16 & & 0.09 & 0.29 & & 0.43 \\
\hline $\begin{array}{l}\text { Model } 2 \text { (HR; } \\
95 \% \mathrm{Cl})\end{array}$ & $\begin{array}{l}0.88 \\
(0.56-1.38)\end{array}$ & Ref. & $\begin{array}{l}1.45 \\
(1.02-2.05)^{\mathrm{a}}\end{array}$ & $\begin{array}{l}1.37 \\
(0.79-2.40)\end{array}$ & Ref. & $\begin{array}{l}1.59 \\
(0.96-2.64)\end{array}$ & $\begin{array}{l}0.61 \\
(0.24-1.54)\end{array}$ & Ref. & $\begin{array}{l}1.25 \\
(0.67-2.34)\end{array}$ \\
\hline$P$ value & 0.57 & & 0.04 & 0.27 & & 0.07 & 0.30 & & 0.49 \\
\hline
\end{tabular}

Ref: reference; ${ }^{C} P<0.001,{ }^{b} P<0.01,{ }^{a} P<0.05$; model 1: a crude hazard ratio model without adjustment for confounders; model 2: a multivariate model adjusted for sex, age, education, occupation, diabetes, hypertension, dyslipidaemia, smoking, alcohol consumption, physical activity, body mass index, self-rated health, cancer, genitourinary disease (including nephropathy, prostatic disease, and gynaecologic diseases), chest disease (including chronic obstructive pulmonary disease, chronic bronchitis, emphysema, asthma, tuberculosis, and pneumonia) and platelet count 
in stroke progression [39]. When aimed specifically to address types of inflammation in mice, allergy (anaphylaxis) induced IL-10 and a corresponding response, while lipopolysaccharide stimulated various types of cells including WBCs to induce the release of a series of active molecules [40]. This is evidence for the effects of different types of inflammation on stroke progression.

We should discuss the corresponding relationship between the risk of fatal stroke occurrence and preexisting chronic low-grade systemic inflammation. Because the GBCS collected a series of data from relatively healthy elderly individuals in South China, each appointment was made in advance to ensure the participant's health and that each participant was able to come the designated place by himself/herself $[32,41]$. To avoid missing important patterns in the relationship between the WBC count and incident fatal stroke, restricted cubic splines were employed, and the analysis showed a relationship between the WBC count on a continuous scale and a $\mathrm{U}$-shaped risk of fatal all stroke occurrence, with high WBC counts being more related to an increased risk than low WBC counts. In the quartile analysis model, a higher WBC count linking the increased risk of fatal all stroke was verified again. In addition, after those with WBC counts at the highest and lowest ends of the range were excluded to avoid intervention during acute inflammatory reactions, our results became consistent with those of some previous reports $[11,13,14]$. The results were reaffirmed after further CRP adjustment, similar to reports from The Japan Collaborative Cohort Study [28] and The Glasgow Inflammation Outcome Study [42]. In contrast to the reports with incongruent factors [15-20], we found that the WBC quartiles showed an increasing risk trend for fatal ischaemic stroke; this weaker association may be due to our added adjustments for self-rated health, genitourinary disease, chest disease, the platelet count and CRP but lack of adjustments for total, HDL and LDL cholesterol, as well as fibrillation level. Nevertheless, a similar association for fatal haemorrhagic stroke disappeared after further adjustments.

As the largest subpopulation of WBCs, NEUTs play an important role in the major processes of atherosclerosis, thrombosis and stroke [43]. Our results are consistent with a few previous reports $[15,19,20]$, though there are other conflicting reports [44-52], showing a higher NEUT count in relation to the increased risk for both fatal all stroke and fatal ischaemic stroke. When the WBC and NEUT counts for fatal stroke are taken into account, our findings suggest that the NEUT count is more conducive to predicting the risk of future fatal stroke occurrence. CRP has been reported to be an independent risk factor in clinical stroke $[9,26,30]$. Here, we observed no significant relationship between CRP and the risk of fatal all stroke (Table 4). This is likely because our analytic data was obtained from relatively healthy participants.

Individuals have different WBC background levels, which can fluctuate by $15 \%$ within 1 day [53]. Stroke events are related to chronic inflammation, while the WBC count can explain the immediate inflammation status well. Based on the baseline data and the first follow-up, we considered unhealthy conditions, random walks and native operation bias as being factors that were related to WBC variation. To guarantee the stability of WBC counts, each participant had an appointment made in advance, with enough time to rest for sampling and a fixed analyser measurement. We report first the risk of fatal all stroke in relation to changes in the WBC and NEUT counts in healthy elderly Chinese individuals. This indicates that an increasing WBC count or continuous chronic inflammation increases the risk of fatal stroke among older Chinese individuals. When WBC and NEUT counts and their dynamic changes are taken into account, it becomes clear that pre-existing chronic lowgrade systemic inflammation plays an important role in future fatal stroke occurrence in the elderly population. This appears to be consistent with the existing body of literature highlighting the adverse cerebrovascular consequences of inflammation. Moreover, we observed an association between WBC count changes and the risk of fatal stroke occurrence in those with WBCs and NEUTs at low levels, although these levels were in the normal range regardless of baseline or the 1st follow-up. Therefore, clinicians should pay more attention to asymptomatic inflammation, especially the dynamic change in WBC counts, to curb the future risk of fatal stroke in a relatively healthy elderly population.

There are limitations in this study. First, we obtained only the death information via record linkage with the GZCDC. Our results, with death as the only outcome, are obviously weakened because of the lack of analysis on other clinical outcomes of stroke events. Second, among a series of potential confounders, inaccurate risk factors such as self-rated health may influence our results because of the high correlation with the objective indicators for health status [54]. Third, as the WBC count of each participant fluctuated, a longitudinal WBC change should be affected because of a native bias in every measurement, although we did more for each participant by making his or her appointment in advance, with sampling performed after an enough time was allowed for rest and conducting the measurement with a fixed analyser. Fourth, we enrolled only those who participated in the 1st follow-up in the study on longitudinal WBC 
changes, which introduces survivorship bias, and the bias was not considered by different types of analysis, such as group-based trajectory modelling or joint modelling of longitudinal and survival data. Fifth, the subjects could not represent Chinese individuals due to the limitations involving the general population in South China in this study. Finally, the small number of deaths limited the strength of this study to address fatal stroke, especially fatal ischaemic stroke and fatal haemorrhagic stroke.

\section{Conclusions}

This first cohort study of relatively healthy Chinese individuals in one of the most economically developed cities in China found that higher WBC and NEUT counts were associated with an increased risk of fatal all stroke. Longitudinal WBC and NEUT count increases in excess of $25 \%$ were also associated with a significantly increased risk of fatal all stroke. Fatal stroke occurrence in China may forewarn the burden of pre-existing chronic low-grade systemic inflammation, especially in the elderly populations of large cities.

\begin{abstract}
Abbreviations
WBC: White blood cell; NEUT: Neutrophil; LYM: Lymphocyte; CRP: C-reactive protein; ICD: International Classification of Diseases; HR: Hazard ratio; aHR: Adjusted HR; CHR: Crude hazard ratio; Cl: Confidence interval; GBCS: Guangzhou Biobank Cohort Study; GZCDC: Guangzhou Centers for Disease Control and Prevention.
\end{abstract}

\section{Supplementary Information}

The online version contains supplementary material available at https://doi. org/10.1186/s12883-021-02495-z.

Additional file 1: Supplementary Table 1 Association between WBCs and fatal all stroke risk in the GBCS, 2003-2017 ( $n=27811)$. Supplementary Table $\mathbf{2}$ Characteristics according to changes in the WBC count of participants in the GBCS $(n=16296)$.

Additional file 2: Supplementary Figure 1 Association between WBCs counts and the risk of fatal stroke among participants of the Guangzhou Biobank Cohort Study, 2003-2017 ( $n=27811)$.

\section{Acknowledgements}

The Guangzhou Biobank Cohort Study investigators included specialists from Guangzhou Twelfth People's Hospital, namely, Weisen Zhang, Min Cao, Tong Zhu, Bin Liu, and Caoqiang Jiang (Co-Pl); the University of Hong Kong, namely, C.M. Schooling, S.M. McGhee, G.M. Leung, R. Fielding, and Taihing Lam (Co-PI); and the University of Birmingham, namely, P. Adab, G Neil Thomas, and Karkeung Cheng (Co-PI).

\section{Authors' contributions}

CQJ, KKC and THL made substantial contributions to the conception and design; FZ and ZBH contributed to acquisition of funding; ZXL, YLJ and JP analysed the data; ZXL, ZBH and FZ wrote the manuscript; WSZ, LX, GNTand THL revised it critically for important intellectual content; and all authors reviewed the manuscript.

\section{Funding}

This work was supported by the Guangzhou Municipal Science and Technology Project $(201704030132,202102080467)$ and the Guangdong Medical Research Foundation (A2021124). The funders had no role in the study design, data collection or analysis, or preparation of the manuscript.

\section{Availability of data and materials}

The datasets used during the current study are available from the corresponding author on reasonable request.

\section{Declarations}

\section{Ethics approval and consent to participate}

The study was approved by the Guangzhou Medical Ethics Committee of the Chinese Medical Association. All participants signed informed consent forms before participation. All methods in this study were performed in accordance with the Declaration of Helsinki.

\section{Consent for publication}

Not applicable.

\section{Competing interests}

The authors declare that they have no competing interests.

\section{Author details}

${ }^{1}$ Guangzhou Twelfth People's Hospital, Guangzhou, China. ${ }^{2}$ School of Public Health, the University of Hong Kong, Pokfulam, Hong Kong. ${ }^{3}$ School of Public Health, Sun Yat-sen University, Guangzhou, China. ${ }^{4}$ Institute of Applied Health Research, University of Birmingham, Sun Yat-sen University, Birmingham, UK.

Received: 18 February 2021 Accepted: 16 November 2021

Published online: 02 December 2021

\section{References}

1. Stroke--1989. Recommendations on stroke prevention, diagnosis, and therapy. Report of the WHO task force on stroke and other cerebrovascular disorders. Stroke. 1989;20(10):1407-31.

2. Murray KN, Buggey HF, Denes A, Allan SM. Systemic immune activation shapes stroke outcome. Mol Cell Neurosci. 2013;53:14-25.

3. Welsh P, Barber M, Langhorne P, Rumley A, Lowe GD, Stott DJ. Associations of inflammatory and haemostatic biomarkers with poor outcome in acute ischaemic stroke. Cerebrovasc Dis. 2009;27(3):247-53.

4. Moskowitz MA, Lo EH, ladecola C. The science of stroke: mechanisms in search of treatments. Neuron. 2010;67(2):181-98.

5. Sun W, Peacock A, Becker J, Phillips-Bute B, Laskowitz DT, James ML. Correlation of leukocytosis with early neurological deterioration following supratentorial intracerebral hemorrhage. J Clin Neurosci. 2012:19(8):1096-100.

6. Parthasarathy S, Steinberg D, Witztum JL. The role of oxidized lowdensity lipoproteins in the pathogenesis of atherosclerosis. Annu Rev Med. 1992:43:219-25.

7. Kazmierski R, Guzik P, Ambrosius W, Ciesielska A, Moskal J, Kozubski W. Predictive value of white blood cell count on admission for in-hospital mortality in acute stroke patients. Clin Neurol Neurosurg. 2004;107(1):38-43.

8. Algin A, Inan I. The role of radiologic, clinical and biochemical parameters in prediction of stroke mortality. Neurosciences (Riyadh). 2019;24(2):110-4.

9. Qu X, Shi J, Cao Y, Zhang M, Xu J. Prognostic value of white blood cell counts and $\mathrm{C}$-reactive protein in acute ischemic stroke patients after intravenous thrombolysis. Curr Neurovasc Res. 2018;15(1):10-7.

10. Ho WM, Lin JR, Wang HH, Liou CW, Chang KC, Lee JD, et al. Prediction of in-hospital stroke mortality in critical care unit. Springerplus. 2016:5(1):1051

11. Brown DW, Ford ES, Giles WH, Croft JB, Balluz LS, Mokdad AH. Associations between white blood cell count and risk for cerebrovascular 
disease mortality: NHANES II mortality study, 1976-1992. Ann Epidemiol. 2004;14(6):425-30.

12. Margolis KL, Manson JE, Greenland P, Rodabough RJ, Bray PF, Safford M, et al. Leukocyte count as a predictor of cardiovascular events and mortality in postmenopausal women: the Women's Health Initiative observational study. Arch Intern Med. 2005;165(5):500-8.

13. Kabagambe EK, Judd SE, Howard VJ, Zakai NA, Jenny NS, Hsieh M, et al. Inflammation biomarkers and risk of all-cause mortality in the reasons for geographic and racial differences in stroke cohort. Am J Epidemiol. 2011;174(3):284-92.

14. Wang T, Jiang $C Q$, Xu L, Zhang WS, Zhu F, Jin YL, et al. White blood cell count and all-cause and cause-specific mortality in the Guangzhou biobank cohort study. BMC Public Health. 2018;18(1):1232.

15. Huh JY, Ross GW, Chen R, Abbott RD, Bell C, Willcox B, et al. Total and differential white blood cell counts in late life predict 8-year incident stroke: the Honolulu heart program. J Am Geriatr Soc. 2015;63(3):439-46.

16. Park JK, Kim HJ, Chang SJ, Koh SB, Koh SY. Risk factors for hemorrhagic stroke in Wonju, Korea. Yonsei Med J. 1998;39(3):229-35.

17. Lee CD, Folsom AR, Nieto FJ, Chambless LE, Shahar E, Wolfe DA. White blood cell count and incidence of coronary heart disease and ischemic stroke and mortality from cardiovascular disease in African-American and white men and women: atherosclerosis risk in communities study. Am J Epidemiol. 2001;154(8):758-64.

18. Koren-Morag N, Tanne D, Goldbourt U. White blood cell count and the incidence of ischemic stroke in coronary heart disease patients. Am J Med. 2005;118(9):1004-9.

19. Zia E, Melander O, Bjorkbacka H, Hedblad B, Engstrom G. Total and differential leucocyte counts in relation to incidence of stroke subtypes and mortality: a prospective cohort study. J Intern Med. 2012;272(3):298-304.

20. Wu TH, Chien KL, Lin HJ, Hsu HC, Su TC, Chen MF, et al. Total white blood cell count or neutrophil count predict ischemic stroke events among adult Taiwanese: report from a community-based cohort study. BMC Neurol. 2013;13:7

21. Gillum RF, Ingram DD, Makuc DM. White blood cell count and stroke incidence and death. The NHANES I epidemiologic follow-up study. Am J Epidemiol. 1994;139(9):894-902.

22. Froyshov HM, Bjornerem A, Engstad T, Halvorsen DS. Elevated inflammatory markers predict mortality in long-term ischemic strokesurvivors: a population-based prospective study. Aging Clin Exp Res. 2017;29(3):379-85.

23. Ohira T, Shahar E, Chambless LE, Rosamond WD, Mosley TH Jr, Folsom AR. Risk factors for ischemic stroke subtypes: the atherosclerosis risk in communities study. Stroke. 2006;37(10):2493-8.

24. Wang L, Song Q, Wang C, Wu S, Deng L, Li Y, et al. Neutrophil to lymphocyte ratio predicts poor outcomes after acute ischemic stroke: a cohort study and systematic review. J Neurol Sci. 2019;406:116445.

25. Freeburn JC, Wallace JM, Strain JJ, Sinnamon DG, Craig BM, Johnson D, et al. Monocyte tissue factor-like activity in post myocardial infarction patients. Br J Haematol. 1998;102(2):605-8.

26. Ye JK, Zhang JT, Kong Y, XU T, Zou TT, Zhang YH, et al. Relationship between white blood cell count, neutrophils ratio and erythrocyte sedimentation rate and short clinical outcomes among patients with acute ischemic stroke at hospital admission. Zhonghua Liu Xing Bing Xue Za Zhi. 2012;33(9):956-60.

27. Walsh KB, Sekar P, Langefeld CD, Moomaw CJ, Elkind MS, Boehme AK et al. Monocyte count and 30-day case fatality in Intracerebral hemorrhage. Stroke. 2015;46(8):2302-4.

28. Iso H, Cui R, Date C, Kikuchi S, Tamakoshi A, Group JS. C-reactive protein levels and risk of mortality from cardiovascular disease in Japanese: the JACC study. Atherosclerosis. 2009;207(1):291-7.

29. Arevalo-Lorido JC, Carretero-Gomez J, Fernandez-Recio JM, Alvarez-Oliva A, Gutierrez-Montano C, Najarro-Diez F, et al. Lowering C-reactive protein with statins after an ischemic stroke avoids mortality and readmissions. A prospective cohort study. Ann Med. 2015;47(3):226-32.

30. Bakhshayesh-Eghbali B, Roudbary SA, Basir Jafari S, Nabizadeh SP, NaderiAsrami N, Sohrabnejad R. Ability of serum C-reactive protein and white blood cell cout in predicting acute schemic stroke. A short -term followup study. Caspian J Intern Med. 2016;7(3):206-10.
31. Lao XQ, Neil Thomas G, Jiang C, Zhang W, Adab P, Lam TH, et al. White blood cell count and the metabolic syndrome in older Chinese: the Guangzhou biobank cohort study. Atherosclerosis. 2008;201 (2):418-24.

32. Phillips AC, Jiang CQ, Thomas GN, Lin JM, Yue XJ, Cheng KK, et al. White blood cell subsets are associated with carotid intima-media thickness and pulse wave velocity in an older Chinese population: the Guangzhou biobank cohort study. J Hum Hypertens. 2012;26(8):485-92.

33. Jiang C, Thomas GN, Lam TH, Schooling CM, Zhang W, Lao X, et al. Cohort profile: the Guangzhou biobank cohort study, a Guangzhou-Hong KongBirmingham collaboration. Int J Epidemiol. 2006;35(4):844-52.

34. Deng HB, Macfarlane DJ, Thomas GN, Lao XQ, Jiang CQ, Cheng KK, et al. Reliability and validity of the IPAQ-Chinese: the Guangzhou biobank cohort study. Med Sci Sports Exerc. 2008;40(2):303-7.

35. Chen C, Lu FC. Department of Disease Control Ministry of health PRC: the guidelines for prevention and control of overweight and obesity in Chinese adults. Biomed Environ Sci. 2004;17(Suppl):1-36.

36. Furlan JC, Vergouwen MD, Fang J, Silver FL. White blood cell count is an independent predictor of outcomes after acute ischaemic stroke. Eur J Neurol. 2014;21(2):215-22.

37. Nayak AR, Kashyap RS, Kabra D, Deoras P, Purohit HJ, Taori GM, et al. Evaluation of routinely performed hematological and biochemical parameters for the prognosis of acute ischemic stroke patients. Neurol Sci. 2011;32(5):855-60.

38. Kammersgaard LP, Jorgensen HS, Nakayama H, Reith J, Raaschou HO, Olsen TS. Leukocytosis in acute stroke: relation to initial stroke severity, infarct size, and outcome: the Copenhagen stroke study. J Stroke Cerebrovasc Dis. 1999;8(4):259-63.

39. Kerr R, Stirling D, Ludlam CA. Interleukin 6 and haemostasis. Br J Haematol. 2001;115(1):3-12.

40. Denes A, Ferenczi S, Kovacs KJ. Systemic inflammatory challenges compromise survival after experimental stroke via augmenting brain inflammation, blood- brain barrier damage and brain oedema independently of infarct size. J Neuroinflammation. 2011:8:164.

41. Li T, Wu XJ, Chen XM, Wang SB, Liu KD, Xing YQ. Ankle-brachial index and brachial-ankle pulse wave velocity are risk factors for ischemic stroke in patients with type 2 diabetes. Neural Regen Res. 2017;12(11):1853-9.

42. Proctor MJ, MCMillan DC, Horgan PG, Fletcher CD, Talwar D, Morrison DS. Systemic inflammation predicts all-cause mortality: a Glasgow inflammation outcome study. PLoS One. 2015;10(3):e0116206.

43. Jickling GC, Liu D, Ander BP, Stamova B, Zhan X, Sharp FR. Targeting neutrophils in ischemic stroke: translational insights from experimental studies. J Cerebr Blood Flow Metab. 2015;35(6):888-901.

44. Song SY, Zhao XX, Rajah G, Hua C, Kang RJ, Han YP, et al. Clinical significance of baseline neutrophil-to-lymphocyte ratio in patients with ischemic stroke or hemorrhagic stroke: an updated meta-analysis. Front Neurol. 2019:10:1032.

45. Qin J, Li Z, Gong G, Li H, Chen L, Song B, et al. Early increased neutrophilto-lymphocyte ratio is associated with poor 3-month outcomes in spontaneous intracerebral hemorrhage. PLoS One. 2019;14(2):e0211833.

46. Giede-Jeppe A, Reichl J, Sprugel MI, Lucking H, Hoelter P, Eyupoglu IY, et al. Neutrophil-to-lymphocyte ratio as an independent predictor for unfavorable functional outcome in aneurysmal subarachnoid hemorrhage. J Neurosurg. 2019:132(2):400-7.

47. Lattanzi S, Cagnetti C, Rinaldi C, Angelocola S, Provinciali L, Silvestrini M. Neutrophil-to-lymphocyte ratio improves outcome prediction of acute intracerebral hemorrhage. J Neurol Sci. 2018;387:98-102.

48. Ye Z, Ai X, Fang F, Hu X, Faramand A, You C. The use of neutrophil to lymphocyte ratio as a predictor for clinical outcomes in spontaneous intracerebral hemorrhage. Oncotarget. 2017:8(52):90380-9.

49. Tao C, Hu X, Wang J, Ma J, Li H, You C. Admission neutrophil count and neutrophil to lymphocyte ratio predict 90-day outcome in intracerebral hemorrhage. Biomark Med. 2017;11(1):33-42.

50. Sun Y, You S, Zhong C, Huang Z, Hu L, Zhang X, et al. Neutrophil to lymphocyte ratio and the hematoma volume and stroke severity in acute intracerebral hemorrhage patients. Am J Emerg Med. 2017;35(3):429-33.

51. Wang F, Hu S, Ding Y, Ju X, Wang L, Lu Q, et al. Neutrophil-to-lymphocyte ratio and 30-day mortality in patients with acute Intracerebral hemorrhage. J Stroke Cerebrovasc Dis. 2016;25(1):182-7. 
52. Zhang F, Ren Y, Fu W, Yang Z, Wen D, Hu X, et al. Predictive accuracy of neutrophil-to-lymphocyte ratio on long-term outcome in patients with spontaneous Intracerebral hemorrhage. World Neurosurg. 2019;125:e651-7.

53. Chamberlain AC, Turner FM, Williams EK. The evaluation of white-cell counting in radiation protection. Br J Radiol. 1952;25(292):169-76.

54. Wagner DC, Short JL. Longitudinal predictors of self-rated health and mortality in older adults. Prev Chronic Dis. 2014;11:E93.

\section{Publisher's Note}

Springer Nature remains neutral with regard to jurisdictional claims in published maps and institutional affiliations.

- fast, convenient online submission

- thorough peer review by experienced researchers in your field

- rapid publication on acceptance

- support for research data, including large and complex data types

- gold Open Access which fosters wider collaboration and increased citations

- maximum visibility for your research: over 100M website views per year

At BMC, research is always in progress.

Learn more biomedcentral.com/submissions 